\title{
Malaria in Open and Closed Communities in Namrole, Buru Selatan District, Maluku Island, Indonesia by Lintang Saraswati
}

Submission date: 28-Sep-2018 05:30PM (UTC+0700)

Submission ID: 1010007440

File name: Lampiran_C1-21_Artikel_utk_turnitin.pdf (430.62K)

Word count: 3043

Character count: 14614 


\title{
Malaria in Open and Closed Communities in Namrole, Buru Selatan District, Maluku Island, Indonesia
}

\author{
Sahrir Sillehu ${ }^{1}$, Heru Santoso Wahito Nugroho ${ }^{2}$, M. Taufan Umasugi ${ }^{1}$, \\ Lintang Dian Saraswati ${ }^{3}$, Praba Ginandjar ${ }^{3}$ \\ 'Institute of Health Science "Maluku Husada", Indonesia; ${ }^{2}$ Health Polytechnic of Ministry of Health in \\ Surabaya, Indonesia; ${ }^{3}$ Department of Epidemiology and Tropical Diseases, Faculty of Public Health, \\ Diponegoro University, Indonesia
}

\begin{abstract}
Malaria remains a public health problem in Buru Selatan District, an area with opened and closed communities. This study aimed to describe malaria prevalence and its related factors in opened and closed communities in Namrole, Buru Selatan District. This study was a cross sectional study to measure prevalence of malaria in open and close communities of Buru Selatan District. Study location was in Namrole Sub-District. Subject was selected by purposive sampling, consisted of 128 subjects (64 subjects from opened community and 64 subjects from closed community). Malaria was diagnosed by thin and thick blood smear. Data was presented as proportion. Statistical analysis used Chi-Square to analyse the data. Characteristics of subject (age, gender, occupation) were equal between malaria and non-malaria subjects, except for age in closed community. Prevalence of malaria in this study was $33.6 \%$ decrease from the prevalence a year earlier (35.5\%). Malaria in closed community was higher than opened community and was clustered in forest. In general, malaria did not relate to behavior although taking medicine differs between malaria and nonmalaria group. Malaria in closed community is higher than opened community, mostly asymptomatic, and clustered in forest. The closed community is an area with traditional life and lack of health facilities. This condition is a challenge in malaria elimination program.
\end{abstract}

Keywords: malaria, opened and closed community, traditional life

8

\section{INTRODUCTION}

Malaria is a disease caused by the Plasmodium parasite, which is transmitted from person 7 person by infected female Anopheles mosquitoes ${ }^{(1)}$. In 2016, 90 countries and areas had ongoing malaria transmission. There were 216 millio 6 cases of malaria in 2016 . The cases were increasing from 211 million cases in 2015. The estimated number of malaria deaths in 2016 was 445000 in 2016, almost similar number to the previous year $(446000))^{(2)}$

Buru Selatan District is a malaria endemic area in Indonesia. From 2011-2014, there were 477, 208,

\section{Corresponding Author:}

Heru Santoso Wahito Nugroho

Health Polytechnic of Ministry of Health in Surabaya, Indonesia

Pucang Jajar Tengah Street 56 Surabaya, Indonesia;

Email: heruswn@gmail.com
361, and 494 malaria cases were reported respectively. Annual blood examination rate (ABER) was 0.91, 0.53, 0.69 and $1.12 \%$ respectively. Slide positive rate (SPR) was $72.49,54.02,71.91$ and $90.91 \%$ from 2011-2014. While annual parasite rate (API) was $6.63,2.89,5.01$ and $6.86 \%$ respectively. ${ }^{(3)}$

There are two communities in Buru Selatan District, open and closed. Closed community is society lives in remote countryside areas, with limited infrastructures. This community lives a traditional vegetative life and depends on nature around. In traditional community, if any family member experiences malaria, they usually use a traditional medicine from natural herbs that surround it. ${ }^{(4)}$ Open community, on the other hand, is society that mostly driven by present's cultural orientation and civilization. They live in urban areas, so called urban society. ${ }^{(5)}$ This study aimed to describe malaria prevalence and its related factors in opened and closed communities in Buru Selatan District. 


\section{MATERIAL AND METHODS}

This cross sectional study measured prevalence of malaria in open and close communities of Buru Selatan District. Selection of the study site was based on two categories: 1. Open or closed community, 2. High endemic of malaria. Selected study sites were Namrole District, which consisted of opened and closed communities. Subject was selected by purposive sampling. Inclusion criteria was subject with malaria, either symptomatic or asymptomatic. This study consisted of 128 subjects, divided into 64 subjects from opene ${ }_{11}$ mmunity and 64 subjects from closed community. Written informed consent was acquired from all subjects. The survey was conducted in May-August 2015.
Malaria was diagnosed by thin and thick blood smear. A volume of $50 \mu \mathrm{L}$ bloods was drawn by finger prick using microtainer $\mathrm{BD}$ blue. The blood from each individual was collected in a slide and prepare for thin and thick blood smear. Malaria was diagnosed if Plasmodium is detected by microscope. Data was presented as proportion. Statistical analysis used ChiSquare to test the difference between positive and negative cases based on sex, age, level of education, occupation and behaviour.

\section{FINDINGS}

This study revealed characteristics of subject were equal between malaria and non-malaria subjects ( $p>0.05)$, except for age in closed community $(p=0.011)$, as seen in Table 1 .

Table 1: Characteristics of study subjects

\begin{tabular}{|c|c|c|c|c|c|c|c|c|c|}
\hline \multirow[b]{2}{*}{ Characteristics } & \multicolumn{2}{|c|}{ Total } & \multirow[b]{2}{*}{$\underset{\text { value }}{p}$} & \multicolumn{2}{|c|}{ Open community } & \multirow[b]{2}{*}{$\begin{array}{c}p \\
\text { value }\end{array}$} & \multicolumn{2}{|c|}{ Closed community } & \multirow[b]{2}{*}{$\begin{array}{c}\mathrm{p} \\
\text { value }\end{array}$} \\
\hline & $\begin{array}{c}\text { Mal (+) } \\
\text { n (\%) }\end{array}$ & $\begin{array}{c}\text { Mal (-) } \\
\text { n (\%) }\end{array}$ & & $\begin{array}{c}\text { Mal (+) } \\
\text { n (\%) }\end{array}$ & $\begin{array}{c}\text { Mal (-) } \\
\text { n (\%) }\end{array}$ & & $\begin{array}{c}\text { Mal (+) } \\
\text { n (\%) }\end{array}$ & $\begin{array}{c}\text { Mal (-) } \\
\text { n (\%) }\end{array}$ & \\
\hline \multicolumn{10}{|l|}{ Gender } \\
\hline - Male & $24(40.0)$ & $36(60.0)$ & 0.149 & $8(27.6)$ & $21(72.4)$ & 0.565 & $16(51.6)$ & $15(48.4)$ & 0.011 \\
\hline - Female & $1(27.9)$ & $49(72.1)$ & & $12(34.3)$ & $23(65.7)$ & & $7(21.2)$ & $26(78.8)$ & \\
\hline \multicolumn{10}{|l|}{ Age } \\
\hline$-0-10$ & $26(36.1)$ & $46(63.9)$ & 0.197 & $11(37.90$ & $18(62.1)$ & 0.133 & $15(34.9)$ & $38(65.1)$ & 0.643 \\
\hline$-11-20$ & $6(40.0)$ & $9(60.0)$ & & $3(33.3)$ & $6(66.7)$ & & $3(50.0)$ & $3(30.0)$ & \\
\hline$-21-30$ & $3(15.8)$ & $16(82.2)$ & & $1(10.0)$ & $9(90.0)$ & & $2(22.2)$ & $7(77.8)$ & \\
\hline$-31-40$ & $3(27.3)$ & $8(72.7)$ & & $1(12.5)$ & $7(87.5)$ & & $2(66.7)$ & $1(33.3)$ & \\
\hline$-41-50$ & $3(33.3)$ & $6(66.7)$ & & $2(33.3)$ & $4(66.7)$ & & $1(33.3)$ & $2(66.7)$ & \\
\hline$->50$ & $2(100.0)$ & $0(0.0)$ & & $2(100.0)$ & $0(0.0)$ & & - & - & \\
\hline \multicolumn{10}{|l|}{ Occupation } \\
\hline - Civil servant & $1(33.3)$ & $2(66.7)$ & 0.946 & $1(33.3)$ & $2(66.7)$ & 0.725 & - & - & 0.782 \\
\hline - Merchants & $2(50.0)$ & $2(50.0)$ & & $1(50.0)$ & $1(50.0)$ & & $1(50.0)$ & $1(50.0)$ & \\
\hline - Farmers & $8(28.6)$ & $20(71.4)$ & & $4(25.0)$ & $12(75.0)$ & & $4(33.3)$ & $8(66.7)$ & \\
\hline - Fishermen & $0(0.0)$ & $1(100.0)$ & & $0(0.0)$ & $1(100.0)$ & & - & - & \\
\hline - Housewife & $0(0.0)$ & $3(100.0)$ & & $0(0.0)$ & $3(100.0)$ & & - & - & \\
\hline - Unemployed & $9(35.4)$ & $53(64.6)$ & & $14(35.9)$ & $25(64.1)$ & & $15(34.9)$ & $28(65.1)$ & \\
\hline - Hunter & $3(42.9)$ & $4(57.1)$ & & & & & $3(42.9)$ & $4(57.1)$ & \\
\hline
\end{tabular}

Note: $\operatorname{Mal}(+)=$ positive malaria; $\operatorname{Mal}(-)=$ negative malaria

In general, prevalence of malaria in this study was $33.6 \%$, while a year earlier the prevalence was $25.6 \%$ in the same subjects. The current prevalence of malaria in closed community (36.0\%) was higher than opened community $(31.2 \%)$, as seen in Table 2 . However, most of malaria in closed community was asymptomatic. In general, malaria did not relate to behavior (Table 3). Distributions of malaria cases in closed community, which can be seen in Figure 1 , were clustered in forest area. 
Table 2: Prevalence of malaria

\begin{tabular}{|c|c|c|c|c|c|c|}
\hline \multirow{2}{*}{ Prevalence } & \multicolumn{2}{|c|}{ Total } & \multicolumn{2}{c|}{ Open community } & \multicolumn{2}{c|}{ Closed community } \\
\cline { 2 - 7 } & $\mathbf{n = 1 2 8}$ & $\mathbf{\%}$ & $\mathbf{n = 6 4}$ & $\mathbf{\%}$ & $\mathbf{n}=\mathbf{6 4}$ & $\mathbf{\%}$ \\
\hline Current malaria & 43 & 33.6 & 20 & 31.2 & 23 & 36.0 \\
\hline Yes & 85 & 66.4 & 44 & 68.8 & 41 & 64.0 \\
\hline No & 11 & 25.6 & 8 & 40.0 & 3 & 13.1 \\
\hline Malaria a year ago & 32 & 74.4 & 12 & 60.0 & 20 & 86.9 \\
\hline Yes
\end{tabular}

Table 3: Relationship between history of malaria and current malaria status

\begin{tabular}{|c|c|c|c|c|c|c|c|c|c|}
\hline \multirow[b]{2}{*}{ Variables } & \multicolumn{2}{|c|}{ Total } & \multirow[b]{2}{*}{ p value } & \multicolumn{2}{|c|}{ Open community } & \multirow[b]{2}{*}{ p value } & \multicolumn{2}{|c|}{ Closed community } & \multirow[b]{2}{*}{ p value } \\
\hline & $\begin{array}{c}\text { Mal (+) } \\
\text { n (\%) }\end{array}$ & $\begin{array}{c}\text { Mal (-) } \\
\text { n (\%) }\end{array}$ & & $\begin{array}{c}\text { Mal (+) } \\
\text { n (\%) }\end{array}$ & $\begin{array}{c}\text { Mal (-) } \\
\text { n (\%) }\end{array}$ & & $\begin{array}{c}\text { Mal (+) } \\
\text { n (\%) }\end{array}$ & $\begin{array}{c}\text { Mal (-) } \\
\text { n (\%) }\end{array}$ & \\
\hline \multicolumn{10}{|c|}{ Experience fever, chill, headache } \\
\hline Symptomatic & $10(22.2)$ & $35(77.8)$ & 0.052 & $6(20.0)$ & $24(80.0)$ & 0.105 & $4(26.7)$ & $11(73.3)$ & 0.297 \\
\hline Asymptomatic & $33(39.8)$ & $50(60.2)$ & & $\begin{array}{c}14 \\
(41.2)\end{array}$ & $20(58.8)$ & & $\begin{array}{c}19 \\
(38.8)\end{array}$ & $30(61.2)$ & \\
\hline \multicolumn{10}{|c|}{ Use traditional herb to cure malaria } \\
\hline Yes & $33(37.1)$ & $56(62.9)$ & 0.207 & $\begin{array}{c}13 \\
(28.9) \\
\end{array}$ & $32(71.1)$ & 0.531 & $\begin{array}{c}20 \\
(45.5)\end{array}$ & $24(54.5)$ & 0.019 \\
\hline No & $10(25.6)$ & $29(74.4)$ & & $7(38.8)$ & $12(63.2)$ & & $3(15.0)$ & $17(85.0)$ & \\
\hline \multicolumn{10}{|c|}{ History of using anti-malaria drugs within 1 years } \\
\hline Yes & $8(28.6)$ & $20(72.4)$ & 0.652 & $6(31.6)$ & $13(68.4$ & 1.000 & $2(22.2)$ & $7(77.8)$ & 0.470 \\
\hline No & $35(35.0)$ & $65(65.0)$ & & $\begin{array}{c}14 \\
(31.1)\end{array}$ & $31(68.9)$ & & $\begin{array}{c}21 \\
(38.2)\end{array}$ & $34(61.8)$ & \\
\hline \multicolumn{10}{|c|}{ Current use of anti-malaria drugs } \\
\hline Yes & $17(24.6)$ & $52(75.4)$ & 0.025 & $6(18.2)$ & $27(81.8)$ & 0.030 & $\begin{array}{c}11 \\
(30.6)\end{array}$ & $25(69.4)$ & 0.431 \\
\hline No & $26(44.1)$ & $33(55.9)$ & & $\begin{array}{c}14 \\
(45.2) \\
\end{array}$ & $17(54.8)$ & & $\begin{array}{c}12 \\
(42.9) \\
\end{array}$ & $16(57.1)$ & \\
\hline \multicolumn{10}{|c|}{ Traveling outside the area } \\
\hline Yes & $6(27.3)$ & $16(72.7)$ & 0.622 & $5(26.3)$ & $14(73.7)$ & 0.769 & $1(33.0)$ & $2(66.7)$ & 1.000 \\
\hline No & $37(34.9)$ & $69(65.1)$ & & $\begin{array}{c}15 \\
(33.3)\end{array}$ & $30(66.7)$ & & $\begin{array}{c}22 \\
(36.1)\end{array}$ & $39(63.9)$ & \\
\hline \multicolumn{10}{|c|}{ Stay temporarily in another area or village } \\
\hline Yes & $9(25.7)$ & $26(74.3)$ & 0.297 & $7(25.9)$ & $20(74.1)$ & 0.586 & $2(25.0)$ & $6(75.0)$ & 0.700 \\
\hline No & $34(36.6)$ & $59(63.4)$ & & $\begin{array}{c}13 \\
(35.1) \\
\end{array}$ & $24(64.9)$ & & $21(37.5)$ & $35(62.5)$ & \\
\hline \multicolumn{10}{|c|}{ Traveled outside the area within 1 year } \\
\hline Yes & $17(32.7)$ & $35(67.3)$ & 1.000 & $5(22.7)$ & $17(77.3)$ & 0.397 & $\begin{array}{c}12 \\
(40.0)\end{array}$ & $18(60.0)$ & 0.606 \\
\hline No & $26(34.2)$ & $50(65.8)$ & & $\begin{array}{c}15 \\
(35.7)\end{array}$ & $27(64.3)$ & & $\begin{array}{c}11 \\
(32.4)\end{array}$ & $23(676)$ & \\
\hline
\end{tabular}


Conted...

\begin{tabular}{|c|c|c|c|c|c|c|c|c|c|c|}
\hline \multicolumn{2}{|c|}{ Traveled to neighboring village within 1 year } \\
\hline Yes & $19(32.8)$ & $39(67.2)$ & 1.000 & $\begin{array}{c}10 \\
(25.0)\end{array}$ & $30(75.0)$ & 0.178 & $9(50.0)$ & $9(50.0)$ & 0.160 \\
\hline No & $24(34.3)$ & $46(65.7)$ & & $\begin{array}{c}10 \\
(41.7)\end{array}$ & $14(58.3)$ & & $\begin{array}{c}14 \\
(30.4)\end{array}$ & $32(69.6)$ & \\
\hline Traveled and stayed for several months in other areas \\
\hline Yes & $35(33.0)$ & $71(67.0)$ & 0.806 & $\begin{array}{c}12 \\
(26.7)\end{array}$ & $33(73.3)$ & 0.250 & $\begin{array}{c}23 \\
(37.7)\end{array}$ & $38(62.3)$ & 0.547 \\
\hline No & $8(36.4)$ & $14(63.6)$ & & $9(42.1)$ & $11(57.9)$ & & $0(0.0)$ & $3(100.0)$ & \\
\hline Travel history \\
\hline Yes & $7(22.6)$ & $24(77.4)$ & 0.137 & $7(22.6)$ & $24(77.4)$ & 0.150 & - & - & - \\
\hline No & $36(37.1)$ & $61(62.9)$ & & $\begin{array}{c}13 \\
(39.4)\end{array}$ & $20(60.6)$ & & $\begin{array}{c}23 \\
(35.9)\end{array}$ & $41(64.1)$ & \\
\hline
\end{tabular}

Note: $\operatorname{Mal}(+)=$ positive malaria; $\operatorname{Mal}(-)=$ negative malaria

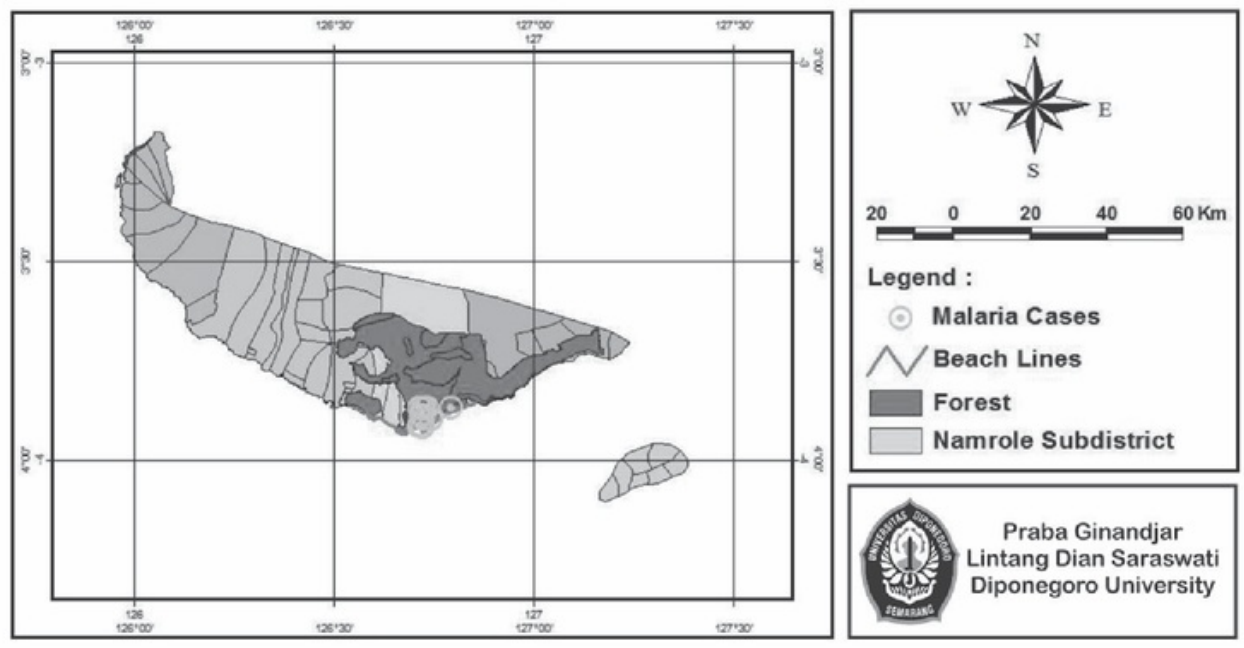

Figure 1: Distribution of malaria cases in open and closed communities

\section{DISCUSSION}

Malaria in closed 3 mmunity was higher than the opened one. This may due to the lack of health facilities in the closed community. Closed (or tribe) community inhabiting mountainous areas and surrounded by forests. This area has not undergone any environmental change, for example agricultural development, settlement, deforestation etc. No health facilities and personne ${ }_{3}$ n closed community. A previous study highlighted the potential of the primary health care system in reaching those most at risk and reducing n 3 laria burden. ${ }^{(6)} \mathrm{A}$ systematic review also revealed community health workers and related cadres had important preventive, case management and promotion roles in malaria interventions. ${ }^{(7)}$

Proportion of asymptomatic malaria was higher than symptomatic malaria. One potential explanation was malaria infections have been occurrifg for a long time in the study area. Immunity, such as antibody and $\mathrm{T}$ cell-mediated immune responses, parasite-induced tolerance, was suggested to involve in the asymptomatic state of malaria. ${ }^{(8)}$ Most people in malaria endemic area are almost continuously exposed by Plasmodium, and the majority of infected adults rarely experience overt disease due to naturally acquired immunity. ${ }^{(9)}$ The existence of asymptomatic malaria is a challenge 
in malaria elimination program as the infections are usually undetectable and rarely treated. ${ }^{(10)}$ The condition of closed community that does not have health facilities makes it more difficult for the malaria elimination program.

In closed community, proportion of malaria in male was significantly higher than female $(p=0.011)$. Traditionally, males in Namrole have responsibility to support their family. The closed community lives as vegetative, utilizes nature, has a natural life, and is dependent on the environment. The agricultural system remains fairly traditional. They mostly work in the forest. This means they 1 re often outdoors and exposed to mosquito bites. The data presented in a study, based on outdoor human landing collections, which clearly emphasized the importance of outdoor malaria transmission in the forest as 5 ell as in the village. ${ }^{(11)} \mathrm{A}$ previous study also revealed men working in the forests had much higher infection rates. Because men tend to 5 gage in more agricultural and forest-related activities, the risk was most likely occupational. ${ }^{(10)}$

As expected, proportion of malaria cases in closed community that used traditional herb was three times higher than modern medicine $(\mathrm{p}=0.011)$. This study revealed closed community lives traditionally, so it can be predicted that they also prefer traditional medicin 2 In closed community, traditional herb usually is decentralized, so it is easily and quickly available to individuals in the community rather than traveling to urban for treatment in public health center. This result was in accordance with a previous study in traditional community, which prefers to use a natural herbs from surrounding environment. ${ }^{(4)} \mathrm{A}$ critical review proved the most common reasons for traditional medicine for malaria across the Asia-Pacific region are a lack of accessibility to conventional health services $d_{2}$ to geographical and financial barriers. ${ }^{(9)}$ Traditional medicine is usually community based. Healers are selected by a corrnunity process that emphasizes personal qualities. Because they are from the community, traditional healers usually know their patients personally, and are well acquainted with their backgrounds, lifestyles and cultural beliefs. (9) This makes the closed community more comfortable doing traditional medication.

On the contrary, proportion of malaria patients who take malaria drug in opened community was higher than those who does not take the drug $(\mathrm{p}=0.030)$. Opened community lives a modern live. There were also health facilities in the area, such as primary health care and hospital. They have easier access to health services than closed community. Full benefits of malaria treatment can only be achieved when a high proportion of patients with 1 alaria have access to effective treatment. ${ }^{(12)}$ Timely access to an authorized malaria drug within 24 hours after fever symptom has been proved to be an important determinant of effective malaria treatment. ${ }^{(13)}$

There was no significant relationship between travel history and malaria occurrence, both in opened and closed communities. Most malaria subjects rarely travel and spend more time living in their respective areas. This should be of concern to local malaria programs to provide good malaria services

Malaria in closed community was higher than opened community. The cases were mostly asymptomatic and clustered in forest. The closed community is an area with traditional life and lack of health facilities. This study may serve as baseline data on the importance of providing health facilities in closed community to support malaria elimination program.

\section{CONCLUSION}

Malaria in closed community is higher than opened community, mostly asymptomatic, and clustered in forest. The closed community is an area with traditional life and lack of health facilities. This condition is a challenge in malaria elimination program.

Conflict-of-interest statement: The authors declare that there is no conflict of interest related to this research.

$$
10
$$

Source of funding: This study was financially supported by the Directorate General of the Higher Education, Ministry of Education and Institute of Research and Community Service of STIKES Maluku Husada (grant number 003.1/STK-LPPM/III/2016).

Ethical clearance: Ethical clearance taken from the Health Research Ethics Committee, Faculty of Public Health, Airlangga University (No: 80-KEPK) on March 23,2015 . 


\section{REFERENCES}

1. Walker NF, Nadjm B, Whitty CJM. Malaria. Medicine (Baltimore). 2017 Dec; In Press.

2. World Healh Organization. WHO | Malaria. WHO. Geneva: World Health Organization; 2017.

3. Dinas Kesehatan Kabupaten Buru Selatan. Profil kesehatan Kabupaten Buru Selatan. Namrole; 2015.

4. Latuconsina. Pataheri and Pasuno Initiation Ritual, Suku Naulu Kabupaten Maluku District. 1st ed. Yogyakarta: Grha Guru; 2013.

5. Kartasasmita G. Karakteristik dan Struktur Masyarakat Modern. 1997 p. 19.

6. O'Meara WP, Noor A, Gatakaa H, Tsofa B, McKenzie FE, Marsh K. The impact of primary health care on malaria morbidity--defining access by disease burden. Trop Med Int Heal. Europe PMC Funders; 2009 Jan;14(1):29-35.

7. Sunguya BF, Munde LB, Ayer R, Jimba M. Towards eliminating malaria in high endemic countries: the roles of community health workers and related cadres and their challenges in integrated community case management for malaria: a systematic review. Malar J. 2017;16(10):1-14.
8. Galatas B, Bassat Q, Mayor A. Malaria Parasites in the Asymptomatic: Looking for the Hay in the Haystack. Trends Parasitol. 2016 Apr;32(4):296-308.

9. Doolan DL, Dobaño C, Baird JK. Acquired immunity to malaria. Clin Microbiol Rev. American Society for Microbiology (ASM); 2009 Jan;22(1):13-36, Table of Contents.

10. Zaw MT, Thant M, Hlaing TM, Aung NZ, Thu $\mathrm{M}$, Phumchuea K, et al. Asymptomatic and submicroscopic malaria infection in Kayah State, eastern Myanmar. Malar J. 2017;16(1):138.

11. Durnez L, Mao S, Denis L, Roelants P, Sochantha $\mathrm{T}$, Coosemans M. Outdoor malaria transmission in forested villages of Cambodia. Malar J. $2013 ; 12: 239$.

12. Khatib RA, Selemani M, Mrisho GA, Masanja IM, Amuri M, Njozi MH, et al. Access to artemisininbased anti-malarial treatment and its related factors in rural Tanzania. Malar J. 2013;12(1): 155.

13. D'Acremont V, Lengeler C, Genton B, Masanja IM, Amuri M, Njozi $\mathrm{MH}$, et al. Reduction in the proportion of fevers associated with Plasmodium falciparum parasitaemia in Africa: a systematic review. Malar J. BioMed Central; 2010 May;9(1):240. 
Malaria in Open and Closed Communities in Namrole, Buru Selatan District, Maluku Island, Indonesia

ORIGINALITY REPORT

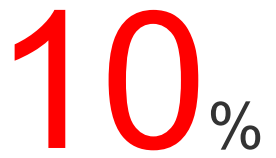

SIMILARITY INDEX
$9 \%$

INTERNET SOURCES
$6 \%$

PUBLICATIONS
$2 \%$

STUDENT PAPERS

PRIMARY SOURCES

1 www.malariajournal.com

Internet Source

2 www.culturalsurvival.org

Internet Source

3 www.ncbi.nlm.nih.gov

Internet Source

4 www.uts.edu.au

Internet Source

Myo Thiha Zaw, Myo Thant, Tin Maung Hlaing,

Naing Zin Aung, Min Thu, Kanit Phumchuea,

Kanokwan Phusri, Teerawat Saeseu,

Ritthideach Yorsaeng, Wang Nguitragool, Ingrid

Felger, Jaranit Kaewkungwal, Liwang Cui,

Jetsumon Sattabongkot. "Asymptomatic and

sub-microscopic malaria infection in Kayah

State, eastern Myanmar", Malaria Journal, 2017

Publication

Submitted to Zionsville Community School 
District

Student Paper

7 Submitted to University of Edinburgh

Student Paper

8

Submitted to University of Witwatersrand

Student Paper

9 biotech-spain.com

Internet Source

Yosuke Inoue, Daichi Takahashi, Naoki Kondo,

Akiko Yoshii, Makoto Sekihara, Francis W

Hombhanje, Takahiro Tsukahara. "Village health

volunteers' individual social capital and

caretakers' health service utilization for febrile

children in Malaria-endemic villages in Papua

New Guinea", Transactions of The Royal

Society of Tropical Medicine and Hygiene, 2017

Publication

Exclude quotes

Exclude bibliography
On

On
Exclude matches

Off 